\title{
A forgotten chapter of Mexican technology and science: Luis Gutiérrez Villegas and poliomyelitis in Mexico
}

\author{
Antonio Velázquez-Arellano
}

Nutrition Genetics Unit of the Institute of Biomedical Investigations, Universidad Nacional Autónoma de México and of the Instituto Nacional de Pediatría, Mexico City, Mexico

\begin{abstract}
Two different types of vaccines were developed against poliomyelitis: The Salk vaccine using inactivated virus and the Sabin one, that was used later, after investigations assured its safety. The first one was made in Mexico with its own resources since 1957 thanks to the efforts of young researchers and technicians coordinated by Luis Gutiérrez-Villegas, M.D., who was a Clinical Pathologist, University Professor and President of the Mexican National Academy of Mexico.
\end{abstract}

KEY WORDS: Poliomyelitis. Vaccine. Salk.

\section{The scourge of poliomyelitis, President F.D. Roosevelt and the "March of dimes"}

In the first half of the past century, poliomyelitis epidemics ravaged the world, which reached very large proportion in summers and left innumerable disabled, paralytic children and caused the death of many others ${ }^{1}$. Summertime epidemics were new, but not the disease, about which there is historical record since ancient Egyptians' times ${ }^{2}$. President Franklin D. Roosevelt had this disease and suffered serious sequels; hence the big support he gave to its care with the National Foundation Against Children's Paralysis and his "March of Dimes" program, which obtained substantial funds to support investigations with the purpose to prevent this illness by means of an efficacious and safe vaccine. Simultaneously with poliomyelitis epidemic outbreaks recrudescence, there were major breakthroughs in knowledge about the virus. Many of advanced countries best scientific minds were fervently devoted to find the way to end with this scourge that was ravaging world's children and many adults as well. Culminating these efforts, the vaccine developed by North American scientist Jonas Salk was shown to be safe and efficacious in 1955 .

\section{A Mexican feat}

In the middle of the past century, Mexico was a country with an incipient scientific infrastructure, with a small number of investigators, practically not a single one dedicated full time, and the expenditure on science and technology was almost inexistent. However, in 1957, Mexico, which had little presence within the international scientific community, achieved the feat of being the second country in the world, after Canada, to produce, exclusively with means of its own, the Salk vaccine, and to start vaccinating hundreds of children, which soon were to become millions ${ }^{3}$. The result was dozens of thousands of children saved from disability and death.

In the chronicle above, I will describe some of the efforts that enabled this achievement, which was the deed of a notable group of people, and I will particularly refer to the person who carried out the main planning, coordination and promotion tasks: Dr. Luis Gutiérrez Villegas (LGV).

\section{Correspondence:}

Antonio Velázquez-Arellano

Av. del Imán, 1, piso 4

Gac Med Mex. 2017;153:576-582 


\section{Luis Gutiérrez Villegas}

He made his professional studies at the National School of Medicine between 1918 and 1924. He took an interest in experimental medicine and in scientific disciplines contributions to medical diagnosis. As a teacher, he trained the first generations of clinical pathologists. In 1943, he founded the Children's Hospital of Mexico clinical laboratories ${ }^{4}$, which were to be the model of scientific support to diagnosis in this hospital and in other new institutions that were created in those days. In 1952, he became president of the National Academy of Medicine of Mexico ${ }^{5}$.

Throughout his entire life, he carried out research work of varied nature, especially taking an interest in viruses and rickettsias and in the diseases caused by them ${ }^{6}$. He made contributions mainly to the knowledge on onchocerciasis, tuberculosis, pinta, brucellosis and poliomyelitis; several of his investigations were carried out in collaboration with doctors Galo Soberón y Parra and Gerardo Varela. He published many of his works at Gaceta Médica de México, the National Academy of Medicine journal.

\section{Two fundamental institutions Mexico confronted poliomyelitis with and a few young scientist heroes}

By the end of the decade of 1940, the devastating poliomyelitis epidemics were recrudesced. LGV's trajectory, succinctly described above, his contributions to medical research, his qualities as an organizer and the esteem and appreciation he enjoyed at scientific, medical, government and business spheres, made of him an ideal leader to confront this epidemic. In the combat that was fought in Mexico against the scorn of poliomyelitis in the decade of 1950, he founded and directed two institutions that had a crucial importance in the fight against poliomyelitis in Mexico: the Center of Studies on Poliomyelitis and the Biological Research Division of the $\mathrm{Na}$ tional Chemical-Pharmaceutical Industry (INQF - Industria Nacional Químico-Farmacéutica). The former was a consulting body where policies and recommendations arose from to trace the pathways for "polio" treatment, rehabilitation and research, as well as funding for different projects on the disease. Its board of trustees was comprised by Antonio Carrillo Flores, Octaviano Longoria, Rafael Mancera, Carlos Novoa, Aarón Sáenz, Carlos Trouyet and Salvador Zubirán, all of them notable doctors, statesmen, bankers and businessmen of those times. As for INQF, it was a government organization that encompassed different German companies that were seized by the Mexican government when our country went to war against the Axis powers. These companies included La Viga, a factory of chemical products; Beick Felix-Stein-México, Guadalajara and Mazatlán, Casa Bayer; General de Anilinas; Insecticidas; Laboratorios Codex; Laboratorios Farquenal; Merck-Knoll-Shering; Casa Lammers; and specially for the purposes of the present work, the Behring Institute?. INQF first chairman was Dr. Salvador Zubirán. The Behring Institute was dedicated to the manufacture of "antisera", and Salvador Zubirán insisted on LGV to manage it, given his previous experience at the Institute of Hygiene. The latter accepted the invitation in 1953, in exchange for the creation of a modern biomedical research center, with full-time posts for young brilliant investigators. It was thus that the INQF Biological Research Division (DIB - División de Investigación Biológica) was created in 1954, within Behring Institute's own property, at the Arenal and Tecoyotitla streets, a few steps away from the Álvaro Obregón park and monument, at Mexico City's south.

If even by today's standards this project sounds ambitious, having it devised early in the 1950 decade in Mexico constituted a real utopia that by all means appeared impossible to be carried out. But never a noble and transcendent idea appeared impossible to Salvador Zubirán; he was thrilled by LGV's proposal, and offered all his support, an important political boost and vision towards the future of Mexico.

The DIB was a milestone in Mexican medical sciences that unfortunately has been almost entirely forgotten today, which had cutting-edge young investigators, adequately remunerated in order for them to dedicate full time to scientific tasks of their choice, although with poliomyelitis as "background". This is how Carlos Campillo Sainz, José Sosa Martínez, Enrique Cifuentes and Raquel Martínez Gracia were hired for virology; Efraín Pardo Codina for pharmacology; José Laguna García for biochemistry; and some younger such as Raúl Ondarza, Victoria Chagoya and Guadalupe Villaseñor, among others. All of them were to be, in a short time, the builders of the new generations of biomedical scientists. However, at the beginning none of them imagined the feat they were meant to accomplish. This ambitious project required scientific vision, great organizational skills and leadership, a combination of freedom with responsibility, trust and confidence together with supervision and excellent administration of limited financial resources; LGV gathered all these qualities.

Over time, Salvador Zubirán went back to run his beloved Nutrition Hospital (current National Institute of Medical Sciences and Nutrition Salvador Zubirán), and 


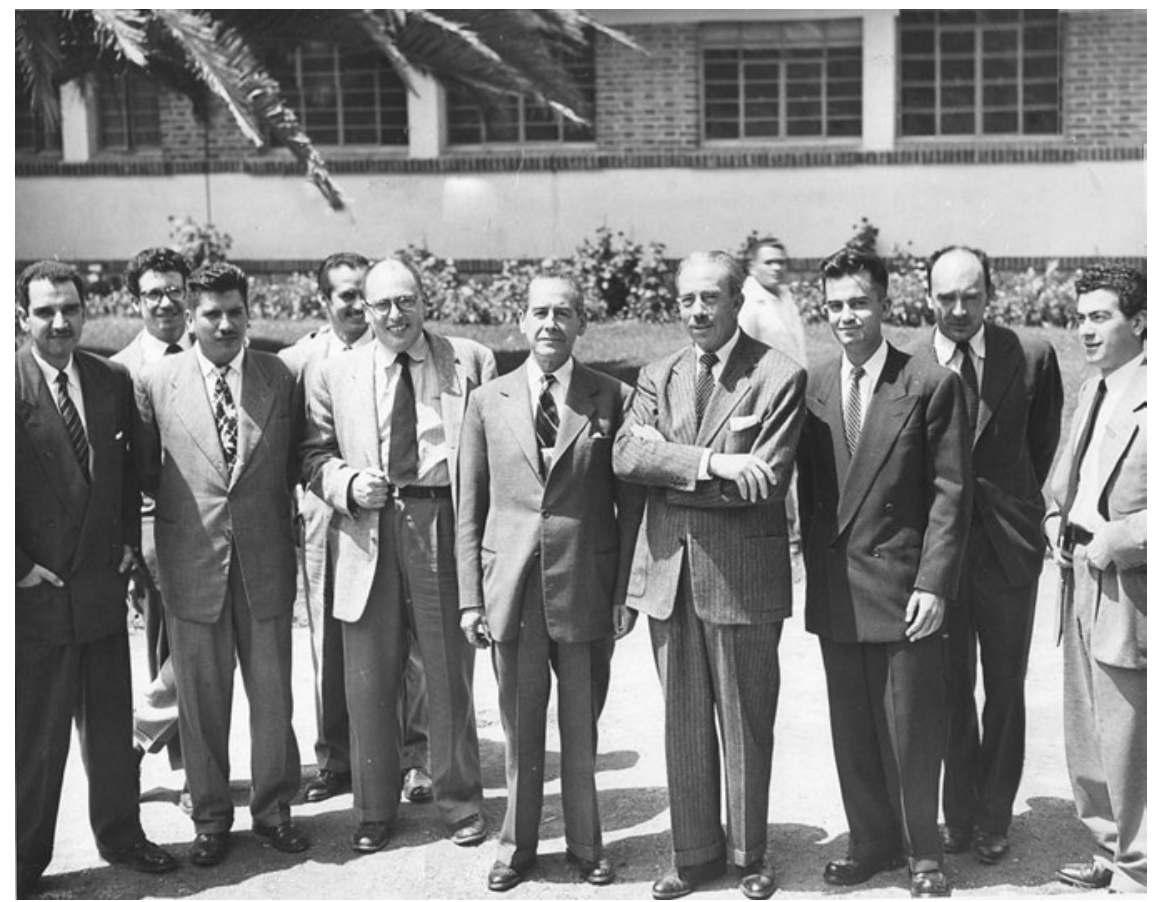

Figure 1. In front of the Biological Research Division, in positions 3-8, doctors Efraín Pardo, Luis Gutiérrez Villegas, Gustavo Baz, accountant Oscar Philibert, José Laguna and Juan Urrusti.

was replaced at INQF by another giant of national medicine, Gustavo Baz, who was in charge to set the DIB in motion in 1954 (Fig. 1). In the introduction of a 1955 not formally published compilation of 18 scientific works that reported the first investigations at the DIB, LGV referred to "the need to make investigative work in the fields of biochemistry, pharmacology and microbiology, about problems of fundamental scientific interest, as well as to promote the study of possible applications these investigations may have, to the benefit of the country".

\section{Two different strategies and a merciless confrontation}

Initially, the fight against "polio" had as only resource hyperimmune gammaglobulin against polioviruses, which had been prepared and used in Mexico since $1952^{8,9}$. For the moment, it was the only line of defense, although poorly efficacious, against the epidemic. The decisive weapon necessarily would have to be a safe and efficacious vaccine. The difficulties to attain it were enormous, since almost everything about the biology of the virus was unknown, and previous attempts in the decades of 1930 and 1940 not only had been complete failures, but the alleged vaccines had caused disability and death in many children'. Attempts had been empirical, of the trial and error type, and the mood was therefore frankly pessimistic and skeptical.
However, the study of bacteria and viruses was the focus of attention of one of the most formidable revolutions in the history of science, which was to lead to current molecular biology ${ }^{10}$. Important advances had also been achieved in the culture of mammalian cells, including human cells and, in 1949, three immunologically-different variables of the poliomyelitis virus with variable immunogenicity and virulence and different antigens were found to exist ${ }^{11}$, which enabled to easily differentiate them in the laboratory. That same year, at Boston Children's Hospital, Dr. John Enders and his collaborators, Fred Robbins and Tom Weller, accomplished the feat of culturing one variety of the virus in Rhesus monkey kidney cells ${ }^{12}$, which opened the possibilities for better understanding the virus, in addition to making for them to be awarded the Nobel Prize in 1954 (together, among others, with Ernest Hemingway and Linus Pauling). With these and other pieces of knowledge, Jonas Salk, at Pittsburg University, started his investigations, the purpose of which was to obtain a reliable vaccine against poliomyelitis ${ }^{13}$.

Since Jenner's first vaccine against smallpox, all vaccines had been developed with virulence-attenuated viruses, unable to cause the disease, but, at the most, some minor discomfort such as fever or headache, but that preserved their immunogenicity, i.e., their capacity to maintain that information in the immune memory so that, in the future, when being invaded by the pathogen, 
the immune system would react by producing an immune response (antibodies) that would defend it and prevent the disease. This is how, for example, the famous vaccine against rabies developed by Louis Pasteur worked.

But by the second half of the 1940 decade, many of the enigmas on the nature of viruses were starting to dissipate. The pioneer experiments of Oswald Avery et al. at the Rockefeller Institute in New York clearly indicated that the genetic material of bacteria, and by extension of all living beings, relied on their nucleic acids (DNA), whereas their immunogenicity depended on their proteins ${ }^{14}$. Thus was that Salk decided to design a vaccine based on a virus with its DNA inactivated with formaldehyde, as he had been doing in previous attempts to obtain a vaccine against influenza. In 1951, he demonstrated its efficacy in monkeys; in 1952, almost secretly, he started inoculating human beings ${ }^{13}$. On the other hand, Albert Sabin had been conducting notable investigations on the poliomyelitis virus since nearly two decades ago and proposed a more traditional vaccine using live, "attenuated" viruses; i.e., as previously explained, that their virulence had been attenuated to the point of not producing clinical disease, but with their antigenicity, their ability to elicit a sufficiently potent response being preserved in order to prevent the disease when the child would be infected with virulent wild viruse ${ }^{15}$. Thus were the bases set for a confrontation that was to be long, fierce and bitter.

In scientific diffusion works, investigators are almost angelical beings who selflessly and with great humbleness devote their entire lives for the sake of humankind. Reality is disappointingly different to this idyllic vision of scientist's biographies for children, which very much resemble the lives of saints. Those who are dedicated to science are human beings as any other, and have all the shadows and the lights of human nature, all its greatness and weaknesses. "Science is a race, a furious competence, where individuals fight to be number one since, without priority, discovery is a bitter fruit"16.

\section{"The largest public health experiment ever made"}

Both because its design was more advanced and for safety reasons, Salk's vaccine was the first one to be tested in 1954, by means of one of the largest and most careful studies ever carried out till that moment ${ }^{17}$. This epidemiological investigation was conducted by Dr. Thomas Francis, director of the prestigious Public Health School of the Michigan University, at Ann Arbor, USA, and Salk's former teacher. Safety and effectiveness of the vaccine were assessed using the procedure known as "double blind": one group of children were vaccinated, while other, which served as control, received only a placebo, but neither the patients, nor their parents, the doctors or nurses that administered the experimental substance knew the identity of the vaccine or the placebo, which was concealed by means of codes that were kept in a safe place. Once the clinical research was carried out, Francis and his collaborators performed the complex statistical analyses in absolute secrecy as long as there was not a clear and conclusive result. It was on April 24, 1955, at the Rackham Auditorium of the University of Michigan Postgraduate School, which was packed with reporters, when Dr. Francis gave the verdict: "the tested poliomyelitis vaccine is safe, efficacious and potent"18. The news spread rapidly around the world; nothing was going to be the same anymore, at summers, for millions of children who previously were at high risk of being left disabled or to die.

In Cincinnati, Albert Sabin managed some time later to develop a different type of vaccine against poliomyelitis based on "live" viruses (able to reproduce), which were also immunogenic, but with considerably reduced virulence $^{19}$, with the risk always present of mutations giving some viruses (very few) their virulence back. In fact, this risk is impossible to be avoided and the consequences have been that some children (also very few) that receive the Sabin vaccine develop the disease, ending up paralytic or dying. But it had a logistical advantage: it could be orally administered, whereas Salk's vaccine required to be injected. In the case of Salk's vaccine, given it uses viruses with inactivated genetic material, the safety factor is only related to aspects of quality control. Sabin never agreed with the use of the vaccine designed by Salk, whom he considered an amateur in the field of poliomyelitis, and he had been tenaciously, but fruitlessly, opposed to Salk's studies and to his vaccine's test, which were funded by the National Foundation against Poliomyelitis - March of Dimes.

What occurred between both scientists was authentically a duel of giants, a duel between two different conceptions about immunization techniques and between two forms to see viruses (remember that, in those days, that what we now call molecular biology was being born) ${ }^{1}$. But the conflict was also between two strong personalities, very different to each other, and there were immense ambitions and mutual envy between both. Salk represented, in a certain form, a new way to practice biomedicine, supported by the new and still debated concepts about the role of 
nucleic acids and proteins in the essence of living beings. Sabin was very different: a man with charisma, who, in addition to being intelligent, was very clever, had a talent for public relations and, in the scientific field, represented orthodoxy, and hence his colleagues saw him as one of them. But the thing that equalized Salk and Sabin is that both were formidable warriors, with unlimited ambitions and implacable in their desires to prevail over the opponent.

Salk had clearly won, but as soon was to be seen, only the first battle, highly important without any doubt, but ultimately only one battle in a war. Sabin by no means considered himself defeated, and he was confident that in time he would win the decisive match. And he wasn't willing to wait too long; as a warrior, he didn't find the problem of attenuated live virus vaccine safety that serous.

\section{A Pyrrhic victory}

Fickle fortune, which had smiled at Salk and turned him into a big hero, suddenly turned her back on him. Three large USA pharmaceutical laboratories had been chosen to manufacture the millions of Salk vaccine doses by means of which all North American children were to be immunized in the shortest time possible. One of them, Cutter Laboratories, had a serious quality control breech in the production of the vaccine: in several batches, the virus was not completely inactivated ${ }^{20}$ and thus, thousands of children, when vaccinated, were applied the live, highly virulent virus and developed the, with many of them being left paralytic or dying. The tragedy made front page headlines of all newspapers in the world and was a serious setback for the trust there was on the Salk vaccine, which its detractors would not miss. The competition between both types of vaccine was no longer scientific and had turned into a battle to the death.

The tragedy provoked by Cutter Laboratories error was like a gift of ammunition for Salk's vaccine enemies, and enabled them to shift from defense to offense. So far, the main argument to hold back the use of the Sabin vaccine, of easy oral administration, had been that of safety; its use implied patience and prudence, and waiting many years of complex epidemiological tests, since it is easier demonstrating something that exists than something that is absent, in this case, attenuated live viruses pathogenic effects absence or very low degree of reversibility. The Salk vaccine, it was passionately argued, in spite of all its limitations and logistic problems, warranted vaccinated children's safety.
Although with no doubt it was a sophism, the argument of Cutter laboratories accident was used as a highly efficacious rhetorical weapon to create the illusion that both vaccines had similar safety risks. This way, this criterion was displaced to a second place, and the Sabin vaccine unquestionable practical benefits were cunningly placed in a priority position. In this battle of egos and power positions, children who were vulnerable to poliomyelitis became secondary.

Subsequently, Salk was marginalized from the world of medicine, especially from pediatrics and public health. With the passage of time, his prestige and memory were redeemed and he was dedicated one of the most important and prestigious institutions where molecular biology was to be developed and is so far practiced at a level of excellence (and also other borderline disciplines, such as neurosciences): the Salk Institute at la Jolla, California.

As one of life's ironies, the World Health Organization recently decided to switch the Sabin for the Salk vaccine!, in the efforts carried out today to completely eradicate poliomyelitis from our planet ${ }^{21}$.

\section{Mexicans were ready... and they made it}

Four or five weeks after Francis announcement about the effectiveness and innocuousness of the Salk vaccine, LGV travelled to the USA accompanied by some of his collaborators, where he carried out conversations for hours and days with Jonas Salk and his team, and also went to visit Sabin in Cincinnati. The Biological Research Division had solid bases in place, the scientists had solidly prepared and trained themselves and, all of this, together with Dr. Salk's generosity, made for this brief trip to become a success, since when they came back to Mexico, everyone, from the director to the humblest worker, fervently undertook a task that a couple years prior would have appeared to be utopian: to produce in Mexico, exclusively with Mexican resources, the vaccine against poliomyelitis, which began to be applied in our country on April $1956^{3,22}$. It is just fair pointing out that, simultaneously with these institutional efforts, links that LGV had been cultivating from time ago with some pharmaceutical companies of the country were set in motion: the Laboratories from Dr. Francisco Zapata Castañeda, engineer José Ignacio Bolívar and Mr. Enrique Chávez Peón Hoffman, director of Lederle Laboratories subsidiary in Mexico, who participated in the production of the vaccine. On November 15, 1955, the Secretary of the Ministry of Public Health and 


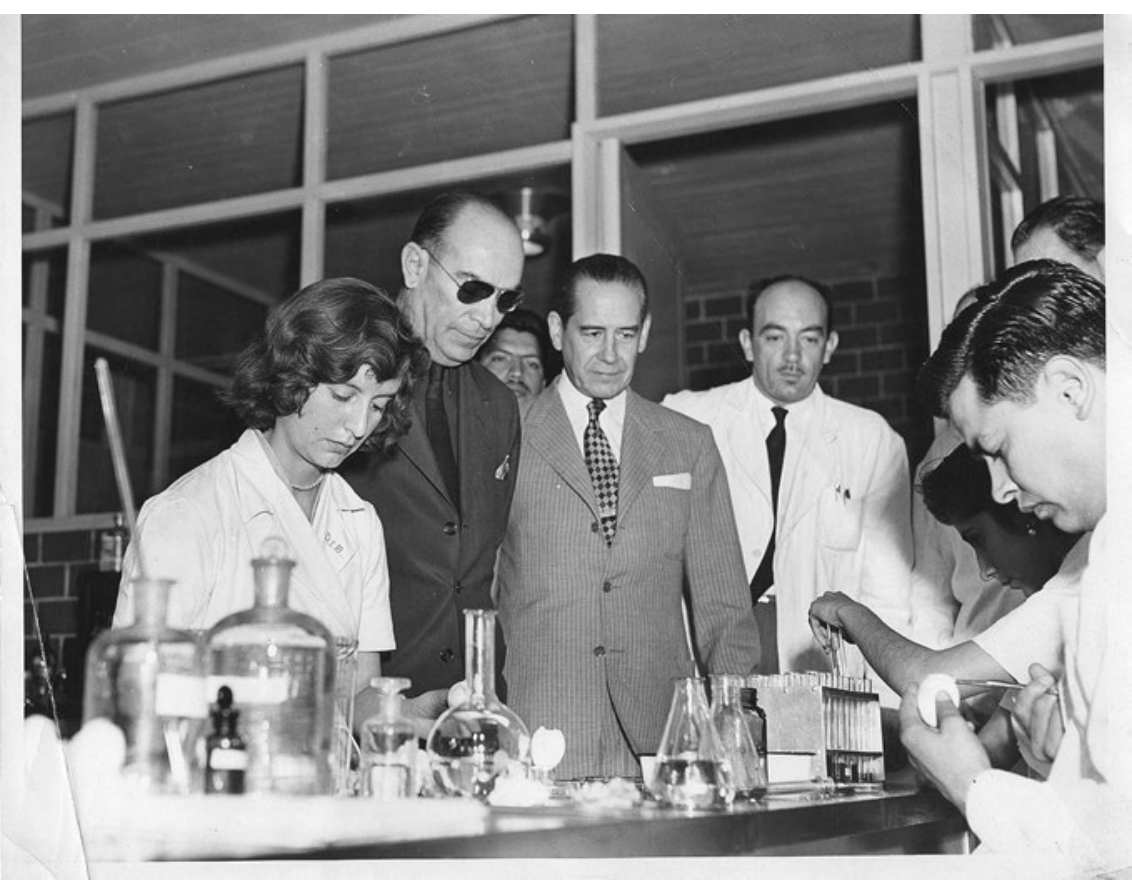

Figure 2. At the Biological Research Division facilities, Beatriz Ordóñez, the Secretary of Public Health and Assistance Ignacio Morones Prieto, Luis Gutiérrez Villegas, José Laguna and Enrique Cifuentes.

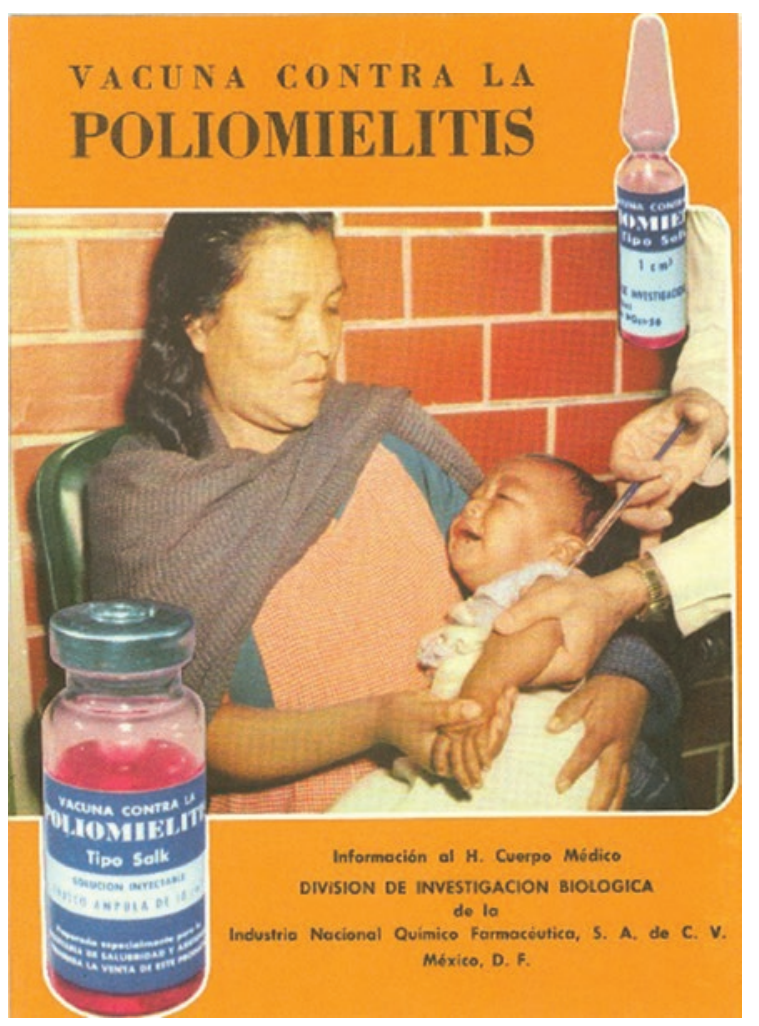

Figure 3. Front page of the brochure on the poliomyelitis vaccine that was widely distributed in Mexico.

Assistance, Dr. Ignacio Morones Prieto, before the President of the Republic, Adolfo Ruiz Cortínez, signed the agreement that founded the National Institute of Children's Wellbeing, with the purpose to gather government and private funds in order to prevent diseases in children, particularly poliomyelitis ${ }^{23}$. With these substantial donations, the country was able to produce the Salk vaccine. Necessary final acquisitions were made, technicians that were still lacking were hired, Rhesus monkeys started being imported from India, and once the first batches of the Salk vaccine entirely produced in Mexico underwent the required safety and effectiveness tests, in 1956, both its production and massive vaccination were set in motion (Figs. 2 and 3). As a result of this, the frequency of poliomyelitis in Mexico started to rapidly decline. As previously mentioned, only Canada was able to produce its vaccine before Mexico.

\section{The rivalry between Salk and Sabin moves to Mexico}

LGV was fully aware of both vaccines advantages and disadvantages. He considered the results of the Sabin vaccine safety studies should be prudently awaited for some time. He had managed to get a grant for a young and promising microbiologist, Manuel Ramos Álvarez, in order for him to have postgraduate studies at Sabin's laboratory in Cincinnati. In Mexico, Dr. Federico Gómez, director and founder of the Children's Hospital of Mexico, took sides for Sabin. Gómez was the leader of Mexican pediatrics, whereas LGV was a laboratory investigator (as previously 
mentioned, he had collaborated with Gómez by establishing the diagnostic laboratories when the Children's Hospital of Mexico was founded). This way, a struggle took place in our country that, in some aspects, was a reflection of that which was taking place in USA between doctors Salk and Sabin. Manuel Ramos Álvarez, the Mexican grant-holder at Sabin's laboratory, who shared many of the personality traits of his teacher, and who wasn't willing to let his colleagues who had stayed in Mexico and were producing the Salk vaccine keep the glory of this achievement, was hired by Dr. Gómez to the Children's Hospital and started efforts to manufacture the Sabin vaccine.

As of 1963, with available results of studies conducted in countries such as Singapore, Czechoslovakia, the USSR and Mexico itself showing the Sabin vaccine innocuousness, it has been applied to all Mexican children ${ }^{24}$. But in 2014, the World Health Organization, in view of the almost complete eradication of the disease worldwide, and given the risks of new outbreaks deriving from the attenuated live virus vaccine (the Sabin vaccine), recommended all countries to use at least one dose of the Salk vaccine with inactivated virus at their systematic vaccination campaigns, at the latest by the end of $2015^{21}$.

\section{Epilogue}

LGV was never interested in power for power itself, nor was he dazzled by fame. He had accepted, practically by force, the direction of the Behring Institute, which he always saw as a challenge to pay, in part, the debt he felt for the many things life and his country had presented him.

In the face of a conflict that was escalating, he decided, paraphrasing that memorable speech delivered at the Professional Jubilee of his great friend Ignacio Chávez, "to pick up his tents, gather his possessions and move somewhere else". He quit the DIB direction, which he had founded, and went back home and to his laboratory. He passed away in 1990.

By the end of the 1950 decade, the Mexican government decided to return to Germany the pharmaceutical and chemical laboratories it had seized when both countries came into conflict during World War II, in order for this and other ways start a new stage of relations between two nations that have always been bound by ties of respect and affection (remember Alexander von Humboldt).

\section{Acknowledgements}

Doctors Silvestre Frenk, Victoria Chagoya, Raúl Ondarza and, very specially, with conscientious, thorough and huge patience, Dr. Ana Cecilia Rodríguez de Romo, critically read the manuscript and made highly valuable recommendations.

The author wrote the manuscript while being the recipient of donations from the Dirección General de Asuntos del Personal Académico de la Universidad Nacional Autónoma de México (PAPIIT IN208214) and from the Consejo Nacional de Ciencia y Tecnología (SEP-CONACYT 166857 Fund).

\section{References}

1. Oshinsky DM. Polio. An American story. Oxford: Oxford University Press; 2005. 342 p.

2. Paul JR. A history of poliomyelitis. New Haven: Yale University Press; 1971. 486 p.

3. Gutiérrez-Villegas L. Resultado de la vacuna contra la poliomielitis, tipo Salk, elaborada en México. Gac Med Mex. 1958;88:319-31.

4. Aguilarpico R. El Hospital Infantil de México. Gac Med Mex. 1963;93:1155-64.

5. Coqui C. El centenario de la Academia Nacional de Medicina. Un justo recuerdo. Gac Med Mex. 1964;94:303-4.

6. Gutiérrez-Villegas L. Symposium de virología. Introducción. Gac Med Mex. 1955;85:231-3.

7. Anónimo. La historia de la Industria Nacional Químico Farmacéutica México: QuimiNet; 2011. Disponible en: http://www.quiminet.com/articulos/la-historia-de-la-industria-nacional-quimico-farmaceutica-1949-2576101.htm

8. Gutiérrez Villegas L, Laguna J, Campillo C, et al. Estudios sobre la immunización pasiva contra la poliomielitis con globulinas homólogas. Gac Med Mex. 1952;82:423-36.

9. Gutiérrez Villegas L. Inmunología y epidemiología de las virosis. Gac Med Mex. 1955;85:243-64.

10. Judson HF. The eighth day of creation: makers of the revolution in biology. Expanded ed. Plainview, N.Y.: CSHL Press; 1996. 714 p.

11. Bodian D. Differentiation of types of poliomyelitis viruses; reinfection experiments in monkeys (second attacks). Am J Hyg. 1949;49:200-23.

12. Enders JF, Weller TH, Robbins FC. Cultivation of the Lansing strain of poliomyelitis virus in cultures of various human embryonic tissues. Science. 1949;109:85-7.

13. Salk JE. Studies in human subjects on active immunization against poliomyelitis. I. A preliminary report of experiments in progress. J Am Med Assoc. 1953;151:1081-98.

14. Avery OT, Macleod CM, McCarty M. Studies on the chemical nature of the substance inducing transformation of pneumococcal types: induction of transformation by a desoxyribonucleic acid fraction isolated from pneumococcus type lii. J Exp Med. 1944;79:137-58.

15. Sabin $A B$. Present status and future possibilities of a vaccine for the control of poliomyelitis. AMA Am J Dis Child. 1953;86:301-10.

16. Broad WJ, Wade N. Betrayers of the truth. New York: Simon and Schuster; 1983. $256 \mathrm{p}$.

17. Salk JE. Vaccination against paralytic poliomyelitis performance and prospects. Am J Public Health Nations Health. 1955;45(5 Pt 1):575-96.

18. Francis T, Jr., Korns RF, Voight RB, et al. An evaluation of the 1954 poliomyelitis vaccine trials. Am J Public Health Nations Health. 1955; 45(5 Pt 2):1-63.

19. Sabin AB. Oral poliovirus vaccine. History of its development and prospects for eradication of poliomyelitis. JAMA. 1965;194:872-6.

20. Offit PA. The Cutter incident, 50 years later. N Engl J Med. 2005:352:1411-2.

21. Roberts $L$. Polio eradication. Rethinking the polio endgame. Science. 2009;323:705.

22. Rodríguez Pérez ME. El Consejo de Salubridad General y las epidemias. México, D.F.: Secretaría de Salud, p. 167.

23. Anónimo. Instituto Nacional de Bienestar de la Niñez. El Universal. 1955, 16 de noviembre; Sect. Primera sección.

24. Wehrle PF, Leedom JM, Portnoy B, et al. Safety of Sabin oral poliovaccine strains; mass immunization program in Los Angeles County, 19621963. JAMA. 1963;186:821-6. 